\title{
Phenol Removal by Novel Choline Chloride Blended Cellulose Acetate-Fly Ash Composite Membrane
}

\author{
Vandana Gupta', Chathurappan Raja'1, Jayapal Anandkumar ${ }^{1 *}$ \\ 1 Department of Chemical Engineering, National Institute of Technology Raipur, \\ Great Eastern Road, Raipur, 490210 Chhattisgarh, India \\ * Corresponding author, e-mail: anandj.che@nitrr.ac.in
}

Received: 02 April 2019, Accepted: 22 May 2019, Published online: 02 July 2019

\begin{abstract}
A novel composite membrane (CM) was prepared by coating choline chloride (ChCl) blended cellulose acetate (CA) on fly-ash based ceramic substrate for phenol removal. Different amount (0-1 g) of $\mathrm{ChCl}$ was blended with CA to synthesize various CMs. Amount of $\mathrm{ChCl}$ in $\mathrm{CA}$ increases the contact angle, average pore radius, permeability of $\mathrm{CM}$ from $55.15^{\circ}$ to $71.55^{\circ}, 1.6$ to $6.83 \mathrm{~nm}$ and 0.0057 to $0.0152 \mathrm{~L} \cdot \mathrm{m}^{-2} \cdot \mathrm{h}^{-1} \cdot \mathrm{kPa}^{-1}$, respectively. Phenol rejection increased from 56 to $93 \%$ while increasing $\mathrm{ChCl}$ amount in CA. Phenol removal decreased from 94.26-64.23\% and 91.09-78.62 \% with increase in applied pressure (69-483 kPa) and feed concentration (50$\left.200 \mathrm{mg} \cdot \mathrm{L}^{-1}\right)$. However, removal rate increased from 80.46-92.47 \% with increase in $\mathrm{pH} 2-12$. Among all $\mathrm{CMs} \mathrm{CC}_{5}$ is identified as best $\mathrm{CM}$ with maximum phenol removal efficiency $(92.7 \%)$ and flux $\left(1.86 \mathrm{~L} \cdot \mathrm{m}^{-2} \cdot \mathrm{h}^{-1}\right)$ at $207 \mathrm{kPa}$ applied pressure and $100 \mathrm{mg} \cdot \mathrm{L}^{-1}$ of feed phenol concentration. The obtained results reveal that blending of $0.9 \% \mathrm{ChCl}$ with CA can significantly enhances the phenol removal efficiency and this could be used as potential CM for treatment of phenol bearing wastewater.
\end{abstract}

Keywords

cellulose acetate, ceramic substrate, choline chloride, composite membrane, phenol removal

\section{Introduction}

Phenol is a primary pollutant and it has adverse effects on human health even at very low concentration. Effluents from many industries such as petrochemical, pharmaceutical, printing press, pulp and paper, coke oven contains phenol and its derivatives [1]. The permissible discharge limit for phenol is $0.5 \mathrm{mg} \cdot \mathrm{L}^{-1}$ in effluent as per EPA (2002). Therefore, the phenol concentration in the effluent must be regulated prior to disposal in the environment. Several methods such as adsorption, wet air oxidation, liquid-liquid extraction, catalytic ozonation, biological degradation, electrocoagulation and deep eutectic mixture are reported for phenol removal [2-9]. However, these methods require excess amount of chemicals, high energy and post processing methods. Major drawbacks of these techniques are cost intensive and low separation efficiency. Hence, there is requisite for alternative technique which is more efficient and economical. Membrane separation by composite membranes could be a better alternative due to its high selectivity towards solute, high separation efficiency, ease to handle and energy efficient [10]. Many literatures are reported about fabrication of polymeric-ceramic CM for wastewater treatment $[1,10,11]$. However, selection of polymeric material to create a suitable active layer is an important and challenging factor. Cellulose acetate (CA) can be a good alternative for efficient coating due to its economical, good strength, solvent resistant, low fouling property and commercial viability as a desalination membrane compared with other polymers $[12,13]$. However, on the other hand, fabrication of polymeric-ceramic CM is expensive due to high cost of substrate. Fabrication cost of substrate can be substantially reduced by using locally available alternative raw materials [14-16]. Mukherjee and De [13] and Hassan et al. [17] have reported merely $51 \%$ and $64 \%$ of phenol removal using CA-alumina nanoparticle mixed matrix membrane and CA hybrid nanofiber membrane, respectively. Phenol removal efficiency and other properties of CA membrane can be improved by using suitable additives [12]. Polyethylene amine, polyurethane and zwitterions are used as suitable blending materials with $\mathrm{CA}$ for efficient removal of $\mathrm{Cu}^{2+}, \mathrm{Cr}^{6+}$ and protein as reported by Chen et al. [18], Riaz et al. [19] and Wang et al. [20], 
respectively. Good phenol removal efficiency of $\mathrm{ChCl}$ is reported by deep eutectic method [21, 22]. $\mathrm{ChCl}$ can also be used as a plasticizer for polymeric films [23, 24]. Therefore, in the present study $\mathrm{ChCl}$ was chosen as efficient blending agent to improve the CA membrane property for phenol removal efficiency.

To the best of author's knowledge, synthesis of $\mathrm{ChCl}-\mathrm{CA}$ coated on fly-ash based ceramic substrate (CC) and its application in phenol removal is not yet reported. Hence, in the present investigation different amounts $\mathrm{ChCl}$ is blended with CA solution to form the active layer on fly-ash ceramic substrate. CC's properties such as chemical stability, wettability, morphology, flux, pore radius and MWCO as well as its phenol removal capacity were also compared with nonblended CA-CM. Operating parameters such as applied pressure; $\mathrm{pH}$ of phenolic feed solution and concentration were studied in detail to achieve the optimum conditions.

\section{Materials and method}

\subsection{Materials}

Cellulose acetate, choline chloride $\left(\mathrm{C}_{5} \mathrm{H}_{14} \mathrm{ClNO}: 98 \%\right)$ and acetone (99 \%) was procured from Loba Chemie Pvt. Ltd., Mumbai, India. Kaolin, boric acid, sodium metasilicate, sodium carbonate, polyethylene glycol (PEG M.W: 1500, 4000, 6000, 10,000 and 20,000), bovine serum albumin and phenol (crystal) were purchased from Merck (India) Pvt. Ltd. Mumbai. Fuller clay was purchased from local supplier and fly ash collected from National thermal power corporation (NTPC) Korba, India. Double distilled water was used for reagents preparation and remaining analysis.

\subsection{Synthesis of composite membrane}

Ceramic substrate was synthesized using predefined composition of fly-ash, fuller clay and other inorganic precursors such as kaolin, boric acid, sodium metasilicate and sodium carbonate. Detailed methodology for preparation of ceramic membrane is reported in our previous study [25]. Subsequently, ceramic substrate was coated upper side with CA solution to obtain the composite membrane.

CA (5 wt\%) solution was prepared using acetone in a closed vessel at ambient temperature $\left(28 \pm 2{ }^{\circ} \mathrm{C}\right)$. Different quantity (0.5-1 g) of $\mathrm{ChCl}$ was slowly blended with CA solution and continuously stirred to attain the homogeneity. Homogenous solution was kept for 15 min ultrasonication to remove the tiny bubbles and coated on ceramic substrate with the help of glass rod. Then CM was dried overnight in ambient temperature. CM prepared with different quantities of
$\mathrm{ChCl}(0,0.5,0.6,0.7,0.8,0.9$ and $1 \mathrm{~g}, \mathrm{w} / \mathrm{w})$ was designated as $\mathrm{CC}_{0}, \mathrm{CC}_{1}, \mathrm{CC}_{2}, \mathrm{CC}_{3}, \mathrm{CC}_{4}, \mathrm{CC}_{5}$ and $\mathrm{CC}_{6}$.

\subsection{Membrane Characterization}

Hydrophilic or hydrophobic nature of CA active layer was examined by contact angle analyzer (Model: Phoenix 300, Make: SEO, Korea). Double distilled water was gently dropped on different sites of active layer and contact angle between active layer as well as droplet was obtained directly by sessile drop technique. Scanning electron microscopic analysis (SEM) (Model EV018: Make: Carl Zeiss, Germany) was performed to investigate the morphological properties of membrane. Fourier transform infrared spectroscopic (Model: Alfa, Make: Bruker, Germany) analysis was carried out to find out the functional groups present in the membrane.

Degree of swelling and chemical stability of CM was measured using gravimetric method. In this method, initially known weight of membrane was immersed in distilled water for $48 \mathrm{~h}$. Then the sample was taken out and wiped gently by tissue paper. Wet and dry weight of sample was measured to estimate the degree of swelling by Eq. (1) [26].

$S_{d}=\frac{W_{s}-W_{d}}{W_{d}} \times 100$

where, $W_{s}$ and $W_{d}$ are wet and dry weight (g) of membrane.

Chemical stability of CM was checked by analyzing permeability and dry weight of membrane before and after immersion in acidic $(\mathrm{pH} \approx 2)$ and basic $(\mathrm{pH} \approx 12)$ medium for $48 \mathrm{~h}$. Hydraulic characteristics of $\mathrm{CM}$ was studied by water compaction which provides rigidness to pores and porous structure after compaction. Compaction study was conducted in a dead-end filtration set-up. This filtration set-up consists of tubular cell with $300 \mathrm{ml}$ capacity and circular base plate possesses membrane holder. $5 \times 0.7 \mathrm{~cm}$ (diameter $\times$ thickness) $\mathrm{ChCl}$ blended CA-fly ash composite membrane was fixed in the membrane holder and edges were sealed with sealant to avoid the league. The effective membrane area of this composite membrane was $18 \mathrm{~cm}^{2}$. Compaction study was carried out with $250 \mathrm{ml}$ distilled water which was pressurized at $483 \mathrm{kPa}$ using nitrogen gas cylinder for $6 \mathrm{~h}$.

Water flux was calculated for every 10 min interval till the steady state condition reached. Pure water flux of compacted CM was measured at different applied pressure $(69-483 \mathrm{kPa})$. The flux $(J)$ through the membrane was calculated by the following Eq. (2): 


$$
\operatorname{Flux}(J)=\frac{V}{A \cdot t}
$$

where, $V, A$ and $t$ are permeate volume (1), membrane area $\left(\mathrm{m}^{2}\right)$ and time (h), respectively.

Molecular weight cut-off(MWCO) study was conducted with different molecular weights of PEG and BSA to obtain the MWCO and pore size of the membrane at $207 \mathrm{kPa}$ and $10 \mathrm{~g} \cdot \mathrm{L}^{-1}$ solute concentration. Abbe Refractometer (Model: 135005, Make: Contech, India) was used to measure solute concentration in feed and permeate. The solute removal $(\% R)$ was calculated by using following Eq. (3):

$\% R=\left(1-\frac{C_{p}}{C_{f}}\right) \times 100$

where $C_{p}$ and $C_{f}$ represent permeate and feed concentration $\left(\mathrm{mg} \cdot \mathrm{L}^{-1}\right)$, respectively. Removal (\%) versus molecular weight curve gives the MWCO values at $90 \%$ rejection of solute. Average pore radius of membrane was estimated by Guerout-Elford-Ferry relation as given by Eq. (4) [13].

$r_{m}=16.73 \times 10^{-10} M_{w}^{0.557}$

where $r_{m}$ and $M_{w}$ are the pore radius (cm) and MWCO (Da) of membrane.

\subsection{Phenol separation from aqueous solution}

Phenol separation efficiency of all CM was tested in deadend filtration setup. Operating parameters such as feed concentration $\left(50-200 \mathrm{mg} \cdot \mathrm{L}^{-1}\right)$, operating pressure $(68-414 \mathrm{kPa})$ and feed $\mathrm{pH}(2-12)$ were optimized to obtain high phenol separation efficiency and permeation flux. Phenol flux and phenol removal (\%) was calculated by using Eqs. (2) and (3), respectively. Feed and permeate phenol concentration was determined by 4-aminoantipyrene method at $500 \mathrm{~nm}$ using UV-Vis spectrophotometer (Model: 1800, Make: Shimadzu, Japan) [27].

\section{Result and discussion}

\subsection{Contact angle, SEM and FTIR analysis}

Contact angle test was performed in order to find the hydrophilic and hydrophobic nature of synthesized CMs. Fig. 1 shows the contact angle obtained between water and CMs. It can be seen in Fig. 1 that there is a slight decline in hydrophilicity of $\mathrm{CM}$ with addition of $\mathrm{ChCl}$. SEM analysis was carried out to study the surface morphology of CM. Fig. 2 shows the SEM images of $\mathrm{CC}_{0}, \mathrm{CC}_{1}$ and $\mathrm{CC}_{6}$ top layer. It can be observed in Fig. 2 that porous structure and porosity of $\mathrm{CM}$ membranes increases with increase in amount of $\mathrm{ChCl} . \mathrm{CC}_{0}$ top layer has stiff and tightly packed

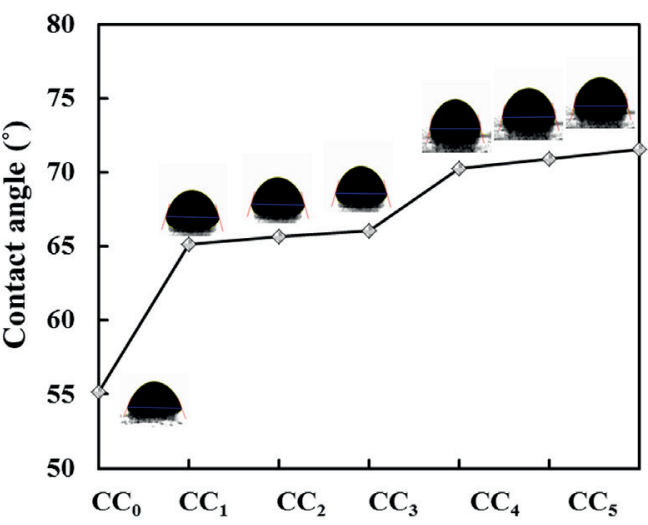

Composite Membrane

Fig. 1 Contact angle of different CMs

structure due to the extensive hydrogen bond in polymeric chain [12]. Addition of $\mathrm{ChCl}$ might reduce the hydrogen bond and increases the free volume by reducing the active cite available for polymer-polymer contact [24]. This leads to increase in contact angle and porous structure.

FTIR spectrum of $\mathrm{CC}_{0}$ and $\mathrm{CC}_{6}$ is shown in Fig. 3. The broad band obtained at 3480 and $3475 \mathrm{~cm}^{-1}$ for $\mathrm{CC}_{0}$ and $\mathrm{CC}_{6}$ is hydroxyl group stretching [17, 28, 29]. Bend at wavenumber of $2944.7 \mathrm{~cm}^{-1}$ for $\mathrm{CC}_{0}$ spectrum is attributed to stretching of $-\mathrm{CH}$ - of methyl groups $\left(-\mathrm{CH}_{3}\right)$, which was shifted to $2948.8 \mathrm{~cm}^{-1}$ for $\mathrm{CC}_{6}$ membrane [30]. The peak for $\mathrm{CC}_{6}$ at $2121.1 \mathrm{~cm}^{-1}$ refers to symmetrical methyl stretching due to blending of $\mathrm{ChCl}$ with $\mathrm{CA}$ [31]. The band near 1950, 1750 and $1650 \mathrm{~cm}^{-1}$ represents multiple bonded $\mathrm{CO}$ group, ester and $\mathrm{C}=\mathrm{C}$ aromatic ring, respectively [29]. Characteristic band around $1431 \mathrm{~cm}^{-1}$ for both the membranes indicate the deformation vibration of $-\mathrm{CH}_{2}$ [28]. Peak at $1051.37 \mathrm{~cm}^{-1}$ for $\mathrm{CC}_{0}$ refers to primary alcohol which is shifted to $1038.1 \mathrm{~cm}^{-1}$ for $\mathrm{CC}_{6}$ and that shows reduction in corresponding molecule [29]. The wavenumber at $1159.9 \mathrm{~cm}^{-1}$ shows the presence of secondary amine in $\mathrm{CC}_{6}$ [29]. Combination of $-\mathrm{C}-\mathrm{O}$ stretching and $-\mathrm{CH}_{2}-$ vibration is also observed at $904.4 \mathrm{~cm}^{-1}$ for both the membrane [28].

\subsection{Swelling and chemical stability test}

The degree of swelling for all CM was calculated by Eq. (1). Fig. 4 shows the swelling effect of different CM. It can be observed that swelling increases with increase in amount of $\mathrm{ChCl}$ blending in $\mathrm{CA}$ due to high water uptake in the enhanced porous structure of $\mathrm{CM}$. This result is in good agreement with $\mathrm{CC}_{0}$ and $\mathrm{CC}_{6} \mathrm{SEM}$ micrographs. Chemical stability test shows that there is negligible $(<1 \%)$ change in the weight loss when $\mathrm{CC}_{0}$ and other $\mathrm{CC}_{6}-\mathrm{CC}_{6}$ were immersed in highly alkaline $(\mathrm{pH} \approx 12)$ and acidic $(\mathrm{pH} \approx 2)$ 

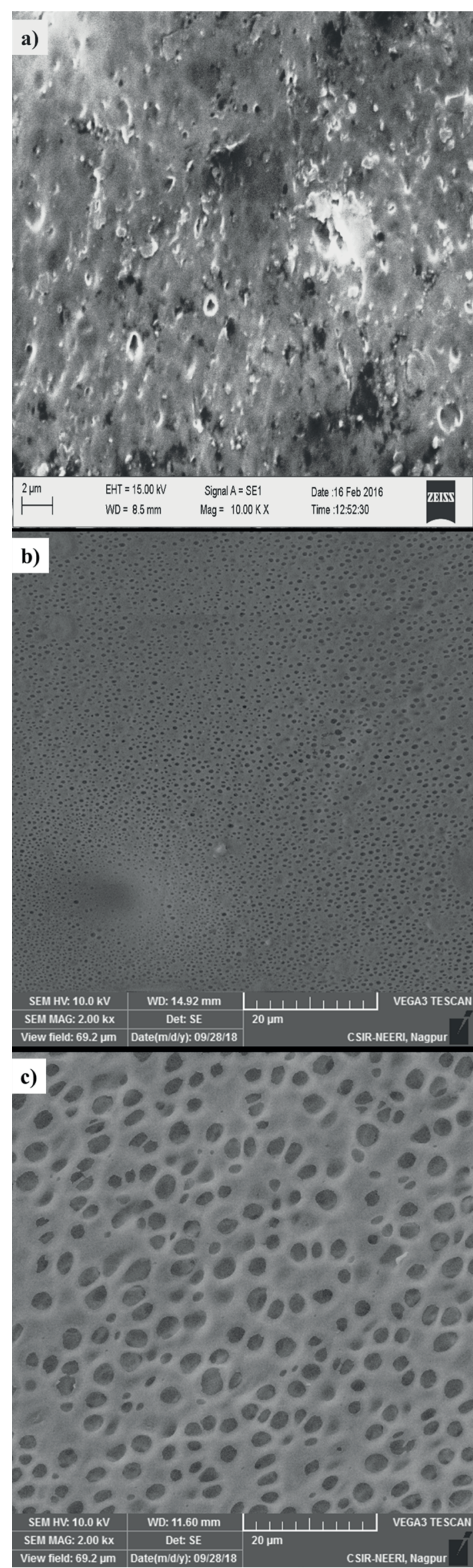

Fig. 2 SEM micrograph of a) $\mathrm{CC}_{0}$, b) $\mathrm{CC}_{1}$ and c) $\mathrm{CC}_{6} \mathrm{CM}$

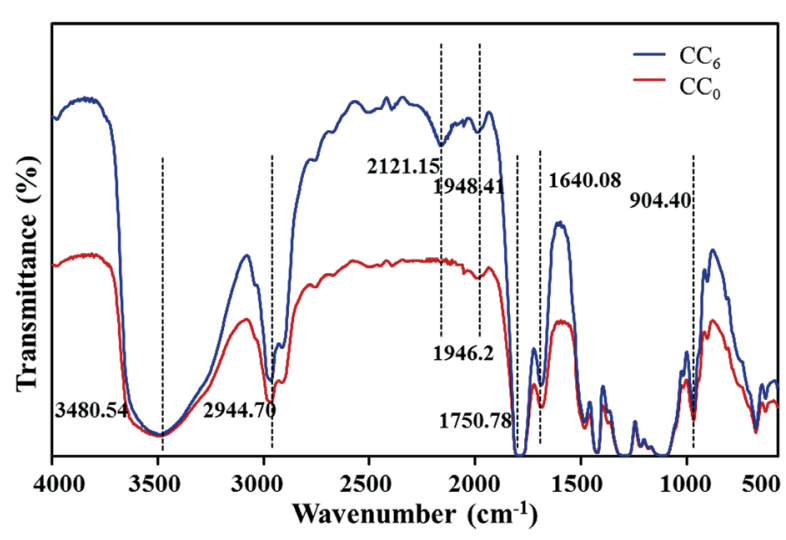

Fig. 3 FTIR spectrum of $\mathrm{CC}_{0}$ and $\mathrm{CC}_{6} \mathrm{CM}$

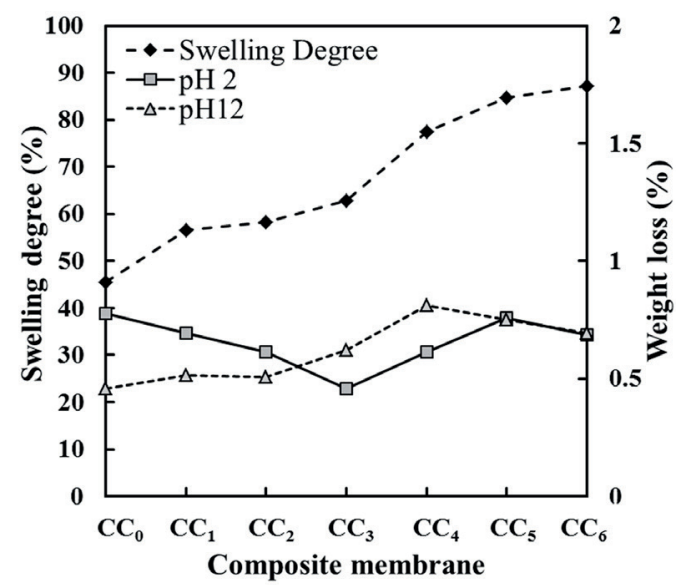

Fig. 4. Effect of swelling degree and chemical stability on different CM

media (Fig. 4). Therefore, it can be concluded that all the membranes are resistive and highly stable even in harsh chemical environment.

\subsection{Pure water flux and MWCO study}

Hydraulic permeability test was conducted to estimate the flux of synthesized $\mathrm{CM}$ at different applied pressure ranging from $69-483 \mathrm{kPa}$ (Fig. 5). It can be seen in Fig. 5 that flux increases with increase in pressure and also slight increase in permeability. Permeability increases from 0.0057 to $0.0152 \mathrm{~L} \cdot \mathrm{m}^{-2} \cdot \mathrm{h}^{-1} \cdot \mathrm{kPa}^{-1}$ for $\mathrm{CC}_{0}$ to $\mathrm{CC}_{6}$, respectively. Applied pressure has notable effect on flux during which impermeable pore also tends to permeate with increase in pressure [32].

In order to obtain the average pore size, MWCO study was conducted with all $\mathrm{CM}\left(\mathrm{CC}_{0}-\mathrm{CC}_{6}\right)$ by using PEG (MW: 1.5, 4, 6, 10 and $20 \mathrm{kDa}$ ) and bovine serum albumin (MW: $64.46 \mathrm{kDa}$ ) at $207 \mathrm{kPa}$. Fig. 6 a) shows the average pore radius of different CMs. MWCO of $\mathrm{CC}_{5}$ corresponding to $90 \%$ rejection of PEG molecule is also shown in Fig. 6 b). It can be seen in Fig. 6 a) that average pore radius of $\mathrm{CM}$ increases from 2.86 to $6.83 \mathrm{~nm}$ with increase of $\mathrm{ChCl}$ 


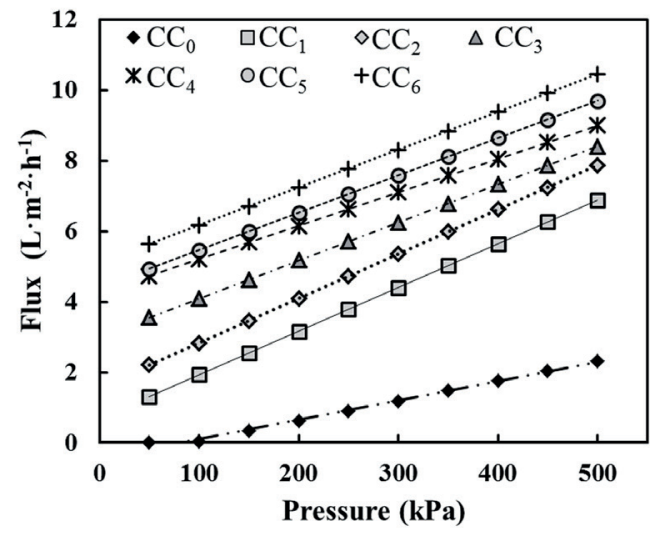

Fig. 5 Effect of pressure on pure water permeation flux for different CMs.

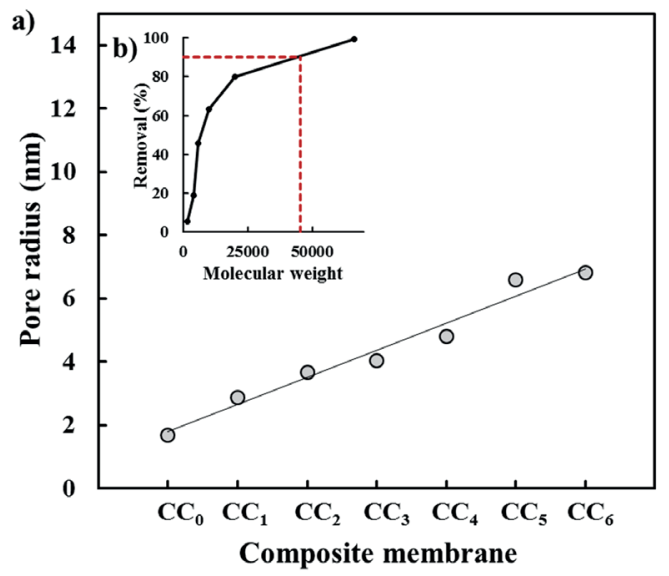

Fig. 6 a) Pore radius of different CMs and b) MWCO of $\mathrm{CC}_{5}$.

blending from 0.5 to $1 \mathrm{~g}$ whereas the $\mathrm{CC}_{0}$ has less pore radius $(1.69 \mathrm{~nm})$. The results of increase in pore size with $\mathrm{ChCl}$ blending amount is also supported by SEM results.

\subsection{Phenol separation}

\subsubsection{Selection of CM}

Selection of appropriate CM is mainly associated with percentage removal of phenol and flux through the membrane. A preliminary phenol removal study was conducted with dead-end filtration setup at constant feed phenol concentration (100 $\left.\mathrm{mg} \cdot \mathrm{L}^{-1}\right)$, applied pressure (207 kPa) and actual pH (5.8). Fig. 7 shows the \% removal and flux of different CM. It can be seen in Fig. 7 that phenol removal and flux increases with increasing the amount of $\mathrm{ChCl}$ in $\mathrm{CA}$. Increase in $\mathrm{ChCl}$ amount increases the number of chloride ions in the top active layer which complexes the associated phenol to retain over the membrane surface. Subsequently, only phenol free water molecules are allowed to pass rapidly through the membrane pores which increase the flux and phenol removal [22].

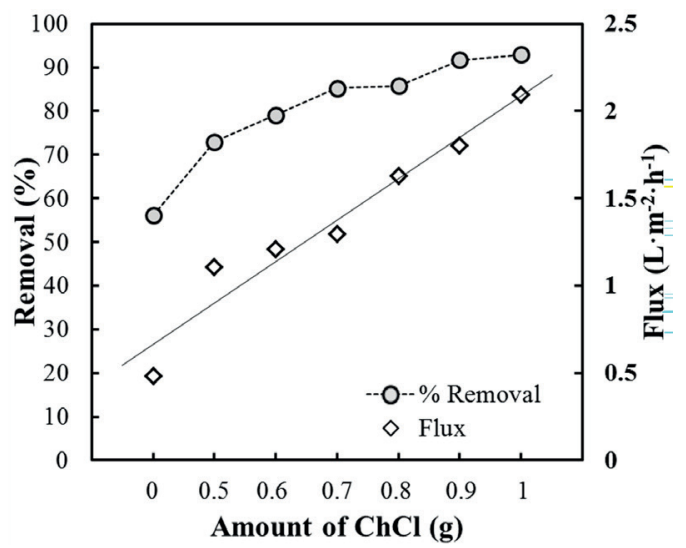

Fig. 7 Effect of $\mathrm{ChCl}$ amount in $\mathrm{CA}$ on phenol removal and flux $\left[\right.$ Feed phenol $=100 \mathrm{mg} \cdot \mathrm{L}^{-1}$, Pressure $=207 \mathrm{kPa}$ and $\left.\mathrm{pH}=5.8\right]$

Moreover, increase in flux is due to the increase in pore size of membrane while increasing the $\mathrm{ChCl}$ amount in CA. Possible interaction mechanism of phenol with $\mathrm{ChCl}$ blended $\mathrm{CA}$ is shown in Scheme 1 [33-35]. Choline chloride $\mathrm{OH}^{-}$group may attach with oxygen atom of hydroxyl group in $\mathrm{CA}$ and releasing hydrogen to form the $\mathrm{H}_{2} \mathrm{O}$ during blending [24]. $\mathrm{CC}_{0} \mathrm{CM}$ has less phenol removal capacity than $\mathrm{ChCl}$ blended $\mathrm{CA}$ membranes which results higher concentration of phenol in the permeate side. Phenol is a hydrogen bond donor due to its partially negative oxygen atom but chloride in $\mathrm{ChCl}$ has large electronegativity which easily forms the strong interaction between $\mathrm{OH}^{-}$group of phenol and chloride ion of ChCl blended CA (Scheme 1) [21, 36].

Hence, maximum removal of phenol was achieved by $\mathrm{CC}_{6}$ membrane due to presence of more chloride ions which favors more removal of phenol than other CMs. Since there is no significant difference in phenol removal

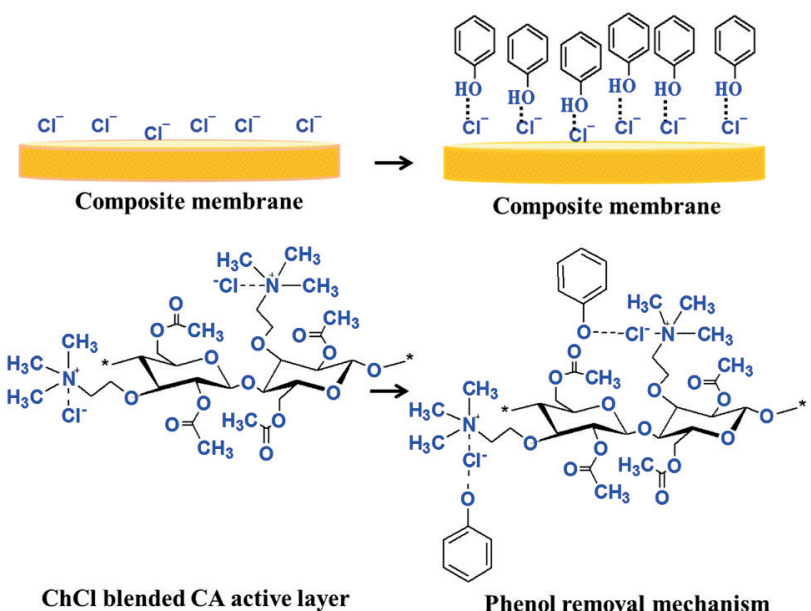

Scheme 1 Interaction mechanism between $\mathrm{ChCl} / \mathrm{CA}$ active layer and phenol 
between $\mathrm{CC}_{5}(91.72 \%)$ and $\mathrm{CC}_{6}(92.92 \%)$, only $\mathrm{CC}_{5}$ was chosen further for all phenol removal studies.

\subsubsection{Effect of Pressure, feed phenol concentration and $\mathbf{p H}$}

Effect of applied pressure on phenol removal and membrane flux was studied at constant operating parameters (Fig. 8 a)). It can be seen in Fig. 8 a) that phenol removal slightly decreases from $94.26 \%$ to $92.33 \%$ while increasing the pressure from 69 to $207 \mathrm{kPa}$ and thereafter removal decreases down to $64.23 \%$ for $414 \mathrm{kPa}$. However, flux gradually increases from $0.64 \mathrm{~L} \cdot \mathrm{m}^{-2} \cdot \mathrm{h}^{-1}$ to $2.3 \mathrm{~L} \cdot \mathrm{m}^{-2} \cdot \mathrm{h}^{-1}$ with increase in pressure from 69 to $414 \mathrm{kPa}$. The increases in pressure increase the driving force which results high flux and phenol concentration in the permeate side [26, 37]. Therefore, $207 \mathrm{kPa}$ was considered as an optimum applied pressure to obtain the good permeation flux $\left(1.54 \mathrm{~L} \cdot \mathrm{m}^{-2} \cdot \mathrm{h}^{-1}\right)$ and phenol removal $(92.33 \%)$.

Effect of feed phenol concentration on phenol removal and flux through $\mathrm{CC}_{5} \mathrm{CM}$ was examined ranging from 50-200 $\mathrm{mg} \cdot \mathrm{L}^{-1}$ by keeping other operating parameters constant. Fig. 8 b) shows the variation in phenol removal \% and flux with respect to change in feed phenol concentration. It can be seen in Fig. 8 b) that phenol removal decreases from 91.09 to $78.62 \%$ with increase in feed phenol concentration from $50-200 \mathrm{mg} \cdot \mathrm{L}^{-1}$ whereas insignificant effect on flux. Increase in phenol concentration at permeate is due to the increase in concentration driving force of phenol molecules as well as molecular friction along with membrane wall surface while increasing the feed concentration [38].

The influence of feed $\mathrm{pH}$ on phenol removal and flux was studied in the range of $\mathrm{pH} 2-12$ at constant operating conditions. Fig. $8 \mathrm{c}$ ) shows the effect of $\mathrm{pH}$ on phenol removal and flux. It can be observed in Fig. 8 c) that flux is unaffected while changing the feed $\mathrm{pH}$ from 2 to 10 whereas phenol removal slowly increases from 80.5 to $92.5 \%$. At high $\mathrm{pH}$ phenol exists in anionic (phenolate anions) form which has electronegative repulsion with negatively charged membrane surface and leads to high phenol removal [39-41].

\section{Conclusion}

In this investigation, novel $\mathrm{ChCl}$ blended $\mathrm{CA}$ was coated on fly-ash based ceramic substrate to prepare the CM for effective removal of phenol. Blending of $\mathrm{ChCl}$ has significant effect on membrane properties such as degree of swelling, chemical stability, pore size, permeability and hydrophilicity. MWCO study showed that increase in pore radius
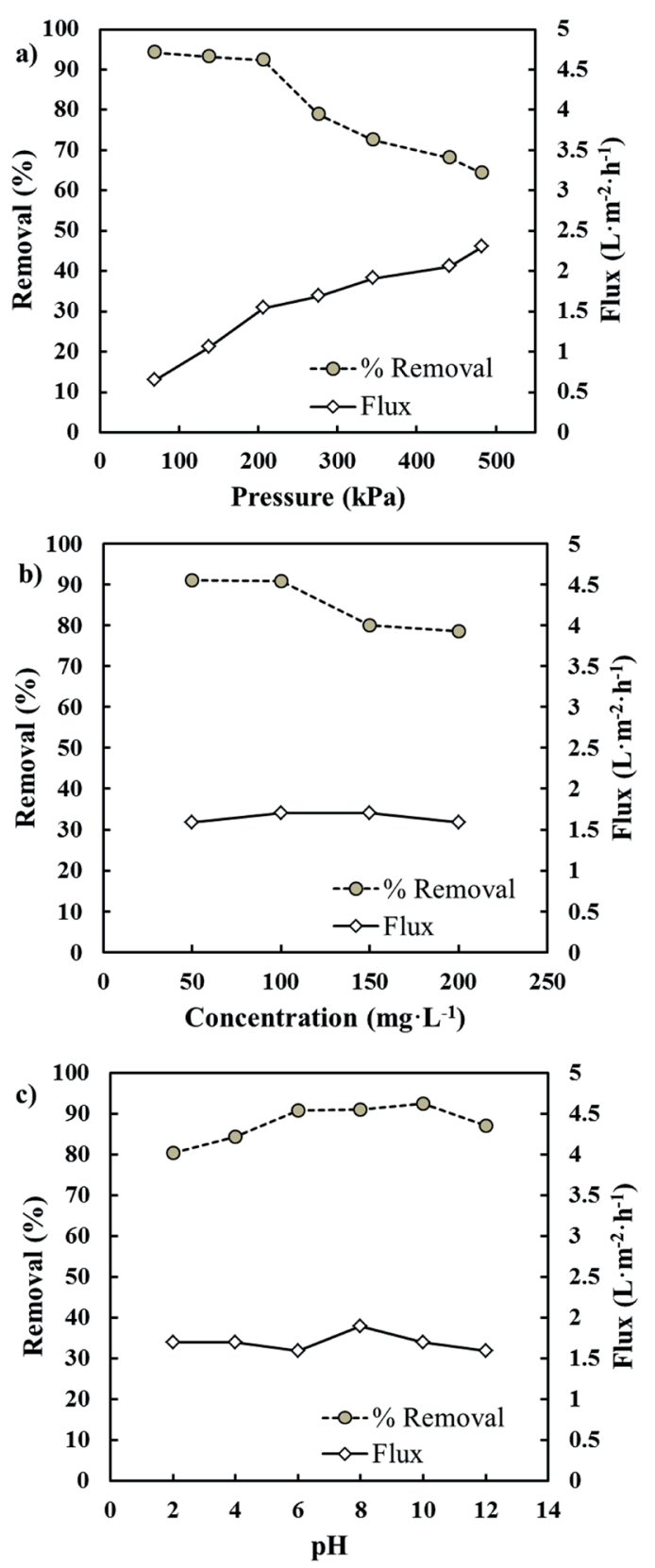

Fig. 8 Effect of a) applied pressure

[Feed concentration $=100 \mathrm{mg} \cdot \mathrm{L}^{-1}$ and $\left.\mathrm{pH}=5.8\right]$,

b) feed phenol concentration $[\mathrm{pH}=5.8$ and applied pressure $=207 \mathrm{kPa}]$, c) feed $\mathrm{pH}$ [Feed concentration $=100 \mathrm{mg} \cdot \mathrm{L}^{-1}$ and applied pressure $=207 \mathrm{kPa}$ ] on phenol removal and flux for $\mathrm{CC}_{5}$.

from 16.88 to $68.32 \mathrm{~nm}$ which also reflected on pure water flux to increase from 2.64 to $12.16 \mathrm{~L} \cdot \mathrm{m}^{-1} \cdot \mathrm{h}^{-1}$ for $\mathrm{CC}_{0}$ to $\mathrm{CC}_{6}$, respectively. In phenol removal study, phenol removal decreased with increasing pressure and feed phenol concentration whereas it was increased with increase in $\mathrm{pH}$. Phenol permeation had increasing trend with pressure but no significant influence with $\mathrm{pH}$ and concentration change. The optimum applied pressure, $\mathrm{pH}$ and concentration 
for high removal of phenol $(92.7 \%)$ and flux $\left(1.86 \mathrm{~L} \cdot \mathrm{m}^{-2} \cdot \mathrm{h}^{-1}\right)$ was identified as $207 \mathrm{kPa}, \mathrm{pH} 10$ and $100 \mathrm{mg} \cdot \mathrm{L}^{-1}$, respectively for $\mathrm{CC}_{5}$. Results obtained in this study confirm that $0.9 \% \mathrm{ChCl}$ blended $\mathrm{CA}$ can be used to fabricate the potential CM for high removal of phenol with good flux.

\section{References}

[1] Xiao, T., Nghiem, L. D., Song, J., Bao, R., Li, X., He, T. "Phenol rejection by cellulose triacetate and thin film composite forward osmosis membranes", Separation and Purification Technology, 186, pp. 45-54, 2017.

https://doi.org/10.1016/j.seppur.2017.05.047

[2] Mukherjee, S., Kumar, S., Mishra, A. K., Fan, M. "Removal of phenols from water environment by activated carbon, bagasse ash and wood charcoal", Chemical Engineering Journal, 129(1-3), pp. 133-142, 2007.

https://doi.org/10.1016/j.cej.2006.10.030

[3] Cao, Y., Li, B., Zhong, G., Li, Y., Wang, H., Yu, H., Peng, F. "Catalytic wet air oxidation of phenol over carbon nanotubes: Synergistic effect of carboxyl groups and edge carbons", Carbon, 133, pp. 464-473, 2018.

https://doi.org/10.1016/j.carbon.2018.03.045

[4] Dai, F., Xin, K., Song, Y., Shi, M., Zhang, H., Li, Q. "Liquid-liquid equilibria for the extraction of phenols from alkane using ethylene glycol", Fluid Phase Equilibria, 419, pp. 50-56, 2016.

https://doi.org/10.1016/j.fluid.2016.03.003

[5] Bao, Q., Hui, K. S., Duh, J. G. "Promoting catalytic ozonation of phenol over graphene through nitrogenation and $\mathrm{Co}_{3} \mathrm{O}_{4}$ compositing", Journal of Environmental Science, 50, pp. 38-48, 2016. https://doi.org/10.1016/j.jes.2016.03.029

[6] Tian, M., Du, D., Zhou, W., Zeng, X., Cheng, G. "Phenol degradation and genotypic analysis of dioxygenase genes in bacteria isolated from sediments", Brazilian Journal of Microbiology, 48(2), pp. 305-313, 2017.

https://doi.org/10.1016/j.bjm.2016.12.002

[7] Zazouli, M. A., Taghavi, M. "Phenol Removal from Aqueous Solutions by Electrocoagulation Technology Using Iron Electrodes: Effect of Some Variables", Journal of Water Resource and Protection, 4(11), pp. 980-983, 2012.

https://doi.org/10.4236/jwarp.2012.411113

[8] Zeng, G.-M., Xu, K., Huang, J.-H., Li, X., Fang, Y.-Y., Qu, Y.-H. "Micellar enhanced ultrafiltration of phenol in synthetic wastewater using polysulfone spiral membrane", Journal of Membrane Science, 310(1-2), pp. 149-160, 2008.

https://doi.org/10.1016/j.memsci.2007.10.046

[9] Guo, W., Hou, Y., Wu, W., Ren, S., Tiana, S., Marsh, K. N. "Separation of phenol from model oils with quaternary ammonium salts via forming deep eutectic solvents", Green Chemistry, 15(1), pp. 226-229, 2013. https://doi.org/10.1039/c2gc36602a

[10] Nataraj, S. K., Roy, S., Patil, M. B., Nadagouda, M. N., Rudzinski, W. E., Aminabhavi, T. M. "Cellulose acetate-coated $\alpha$-alumina ceramic composite tubular membranes for wastewater treatment", Desalination, 281, pp. 348-353, 2011.

https://doi.org/10.1016/j.desal.2011.08.016

\section{Acknowledgement}

This work is supported by a grant of Department of Science and Technology (SERB), New Delhi, Government of India, under the scheme of Start-up Research Grant (ECR/2016/000435; Dated 09-09-2016).

[11] Gupta, V., Anandkumar, J. "Synthesis of crosslinked PVA-ceramic composite membrane for phenol removal from aqueous solution", Journal of the Serbian Chemical Society, 84(2), pp. 211-224, 2019. https://doi.org/10.2298/JSC180424083G

[12] Puspasari, T., Pradeep, N., Peinemann. K.-V. "Crosslinked cellulose thin film composite nanofiltration membranes with zero salt rejection", Journal of Membrane Science, 491, pp. 132-137, 2015. https://doi.org/10.1016/j.memsci.2015.05.002

[13] Mukherjee, R., De, S. "Adsorptive removal of phenolic compounds using cellulose acetate phthalate-alumina nanoparticle mixed matrix membrane", Journal Hazardous Material, 265, pp. 8-19, 2014. https://doi.org/10.1016/j.jhazmat.2013.11.012

[14] Vasanth, D., Pugazhenthi, G., Uppaluri, G. "Fabrication and properties of low cost ceramic microfiltration membranes for separation of oil and bacteria from its solution", Journal of Membrane Science, 379(1-2), pp. 154-163, 2011. https://doi.org/10.1016/j.memsci.2011.05.050

[15] Jedidi, I., Khemakhem, S., Saïdi, S., Larbot, A., Elloumi-Ammar, N., Fourati, A., Charfi, A., Salah, A. B., Amar, R. B. "Preparation of a new ceramic microfiltration membrane from mineral coal fly ash: Application to the treatment of the textile dying effluents", Powder Technology, 208(2), pp. 427-432, 2011. https://doi.org/10.1016/j.powtec.2010.08.039

[16] Hofman, J. A. M. H., Beerendonk, E. F., Folmer, H. C., Kruithof, J. C. "Removal of pesticides and other micropollutants with celluloseacetate, polyamide and ultra-low pressure reverse osmosis membranes", Desalination, 113(2-3), pp. 209-214, 1997. https://doi.org/10.1016/S0011-9164(97)00131-8

[17] Hassan, H. S., Elkady, M. F., Farghali, A. A., Salem, A. M., Abd El-Hamid, A. I. "Fabrication of novel magnetic zinc oxide cellulose acetate hybrid nano-fiber to be utilized for phenol decontamination", Journal of the Taiwan Institute of Chemical Engineering, 78, pp. 307-316, 2017. https://doi.org/10.1016/j.jtice.2017.06.021

[18] Chen, Z., Deng, M., Chen, Y., He, G., Wu, M., Wang, J. "Preparation and performance of cellulose acetate / polyethyleneimine blend microfiltration membranes and their applications", Journal of Membrane Science, 235(1-2), pp. 73-86, 2004. https://doi.org/10.1016/j.memsci.2004.01.024

[19] Riaz, T., Ahmad, A., Saleemi, S., Adrees, M., Jamshed, F., Hai, A. M., Jamil, T. "Synthesis and characterization of polyurethane-cellulose acetate blend membrane for chromium (VI) removal", Carbohydrate Polymers, 153, pp. 582-591, 2016. https://doi.org/10.1016/j.carbpol.2016.08.011

[20] Wang, P., Meng, J., Xu, M., Yuan, T., Yang, N., Sun, T., Zhang, Y., Feng, X., Cheng, B. "A simple but efficient zwitterionization method towards cellulose membrane with superior antifouling property and biocompatibility", Journal of Membrane Science, 492, pp. 547-558, 2015. https://doi.org/10.1016/j.memsci.2015.06.024 
[21] Guo, W., Hou, Y., Ren, S., Tiana, S., Wu, W. "Formation of Deep Eutectic Solvents by Phenols and Choline Chloride and Their Physical Properties", Journal of Chemical \& Engineering Data, 58(4), pp. 866-872, 2013. https://doi.org/10.1021/je300997v

[22] Zhu, J., Yu, K., Zhu, Y., Zhu, R., Ye, F., Song, N., Xu, Y. "Physicochemical properties of deep eutectic solvents formed by choline chloride and phenolic compounds at $T=(293.15$ to 333.15$) \mathrm{K}$ : The influence of electronic effect of substitution group", Journal of Molecular Liquids, 232, pp. 182-187, 2017. https://doi.org/10.1016/j.molliq.2017.02.071

[23] del Monte, F., Carriazo, D., Serrano, M. C., Gutiérrez, M. C., Ferrer, M. L. "Deep Eutectic Solvents in Polymerizations: A Greener Alternative to Conventional Syntheses", ChemSusChem: Chemistry \& Sustainability, Energy \& Materials, 7(4), pp. 999-1009, 2014. https://doi.org/10.1002/cssc.201300864

[24] Wang, S., Peng, X., Zhong, L., Jing, S., Cao, X., Lu, F., Sun, R. "Choline chloride / urea as an effective plasticizer for production of cellulose films", Carbohydrate Polymers, 117, pp. 133-139, 2015. https://doi.org/10.1016/j.carbpol.2014.08.113

[25] Gupta, V., Anandkumar, J. "Protein Separation Using Fly-ash Microfiltration Ceramic Membrane", CSVTU International Journal of Biotechnology, Bioinformatics and Biomedical, 3(2), pp. 17-25, 2018. https://doi.org/10.30732/ijbbb.20180302002

[26] Li, S.-Y., Srivastava, R., Parnas, R. S. "Separation of 1-butanol by pervaporation using novel tri-layer PDMS composite membrane", Journal of Membrane Science, 363(1-2), pp. 287-294, 2010. https://doi.org/10.1016/j.memsci.2010.07.042

[27] Rice, E. W., Baird, R. B., Eaton, A. D., Clesceri, L. S. "APHA 5530 Standard Methods for the Examination of Water and Wastewater", American Public Health Association, American Water Works Association, Water Environment Federation, Washington, DC, USA, 2012.

[28] Sudiarti, T., Wahyuningrum, D., Bundjali, B., Arcana, I. M. "Mechanical strength and ionic conductivity of polymer electrolyte membranes prepared from cellulose acetate-lithium perchlorate", IOP Conference Series: Material Science and Engineering, 223, article ID: 012052, 2017. https://oi.org/10.1088/1757-899X/223/1/012052

[29] Coates, J. "Interpretation of Infrared Spectra, A Practical Approach", In: Meyers, R. A. (ed.) Encyclopedia of Analytical Chemistry, John Wiley \& Sons Ltd, Chichester, England, 2000, pp. 10815-10837.

[30] Delgado-Mellado, N., Larriba, M., Navarro, P., Rigual, V., Ayuso, M., García, J., Rodríguez, F. "Thermal stability of choline chloride deep eutectic solvents by TGA/FTIR-ATR analysis", Journal of Molecular Liquids, 260, pp. 37-43, 2018. https://doi.org/10.1016/j.molliq.2018.03.076
[31] Knapp, D., Brunschwig, B. S., Lewis, N. S. "Transmission Infrared Spectra of $\mathrm{CH}_{3-}, \mathrm{CD}_{3-}$, and $\mathrm{C}_{10} \mathrm{H}_{21-} \mathrm{Ge}(111)$ Surfaces", The Journal of Physical Chemistry, 115(33), pp. 16389-16397, 2011. https://doi.org/10.1021/jp110550t

[32] Baker, R. W. "Membrane Technology and Applications", 2nd ed., John Wiley \& Sons Ltd, Chichester, England, 2012.

[33] Bhosle, M. R., Khillare, L. D., Dhumal, S. T., Mane, R. A. "A facile synthesis of 6-amino-2H, $4 H$-pyrano [2,3-c] pyrazole-5-carbonitriles in deep eutectic solvent", Chinese Chemical Letters, 27(3), pp. 370-374, 2016. https://doi.org/10.1016/j.cclet.2015.12.005

[34] Li, L., Hu, Y., Cheng, F. "Butyration of Lignosulfonate with Butyric Anhydride in the Presence of Choline Chloride", Bio Resources, 10(2), pp. 3181-3196, 2015.

[35] Zhu, A., Jiang, T., Han, B., Zhang, J., Xie, Y., Ma, X. "Supported choline chloride / urea as a heterogeneous catalyst for chemical fixation of carbon dioxide to cyclic carbonates", Green Chemistry, 9(2), pp. 169-172, 2007. https://doi.org/10.1039/b612164k

[36] Francisco, M., van den Bruinhorst, A., Kroon, M. C. "Low-Transition-Temperature Mixtures (LTTMs): A New Generation of Designer Solvents", Angewandte Chemie International Edition, 52(11), pp. 3074-3085, 2013. https://oi.org/10.1002/anie.201207548

[37] Nandi, B. K., Uppaluri, R., Purkait, M. K. "Effect of dip coating parameters on the morphology and transport properties of cellulose acetate-ceramic composite membranes", Journal of Membrane Science, 330(1-2), pp. 246-258, 2009. https://doi.org/10.1016/j.memsci.2008.12.071

[38] Al-Obaidi, M. A., Kara-Zaïtri, C., Mujtaba, I. M. "Removal of phenol from wastewater using spiral-wound reverse osmosis process: Model development based on experiment and simulation", Journal of Water Process Engineering, 18, pp. 20-28, 2017. https://doi.org/10.1016/j.jwpe.2017.05.005

[39] Djamila, G., Djamel, A., Nedjla, A. "Selective Adsorption of 2-nitrophenol, Phenol, Hydroquinone on Poly (Vinyl Alcohol) Crosslinked Glutaraldehyde- $\beta$-cyclodextrin Polymer Membrane", Journal of Polymer and Biopolymer Physics Chemistry, 4(1), pp. 7-15, 2016. https://doi.org/10.12691/jpbpc-4-1-2

[40] Li, Y., Wei, J., Wang, C., Wang, W. "Comparison of phenol removal in synthetic wastewater by NF or RO membranes", Desalination and Water Treatment, 22(1-3), pp. 211-219, 2010. https://doi.org/10.5004/dwt.2010.1787

[41] László, K., Tombácz, E., Josepovits, K. "Surface Characterization of a Polyacrylonitrile Based Activated Carbon and the Effect of $\mathrm{pH}$ on Its Adsorption from Aqueous Phenol and 2,3,4-trichlorophenol Solution", Periodica Polytechnica Chemical Engineering, 47(2), pp. 105-116, 2003. [online] Available at: https://pp.bme.hu/ ch/article/view/260 [Accessed: 15 May 2019] 